$1-1-1964$

\title{
Ornamentals : Consumer response to : 1 , Distribution of literature : 2 , A free landscape sketching service
}

Roger W. Pease

Follow this and additional works at: https://researchrepository.wvu.edu/ wv_agricultural_and_forestry_experiment_station_bulletins

\section{Digital Commons Citation}

Pease, Roger W., "Ornamentals : Consumer response to : 1, Distribution of literature : 2, A free landscape sketching service" (1964). West Virginia Agricultural and Forestry Experiment Station Bulletins. 491.

https://researchrepository.wvu.edu/wv_agricultural_and_forestry_experiment_station_bulletins/459 @ WVU. It has been accepted for inclusion in West Virginia Agricultural and Forestry Experiment Station Bulletins by an authorized administrator of The Research Repository @ WVU. For more information, please contact ian.harmon@mail.wvu.edu. 
3 13.

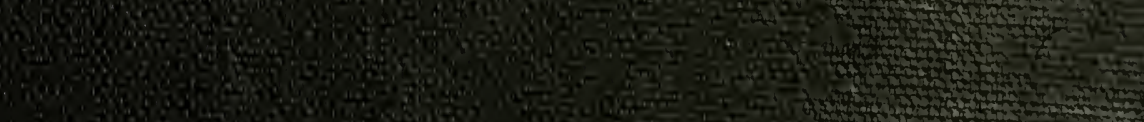

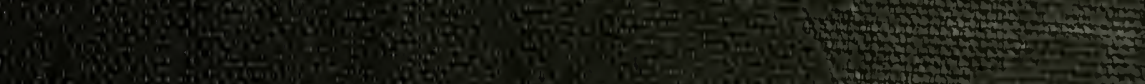

F.

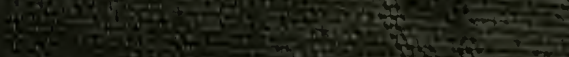

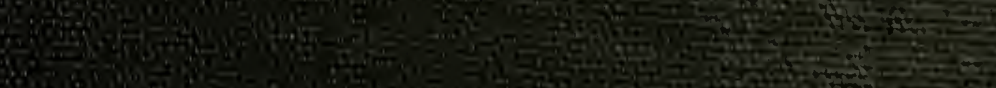

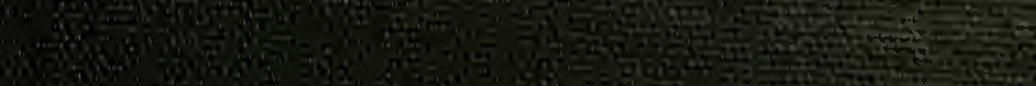

X.

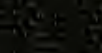

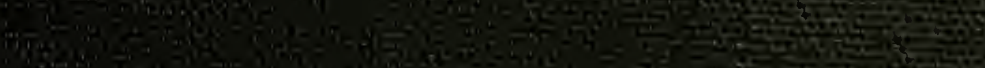
cis 
Digitized by the Internet Archive in 2010 with funding from Lyrasis Members and Sloan Foundation 
Bulletin 491, May 1964

\section{ORNAMENTALS- Consumer Response to}

1. Distribution of Literature

2. A Free Landscape Sketching Service

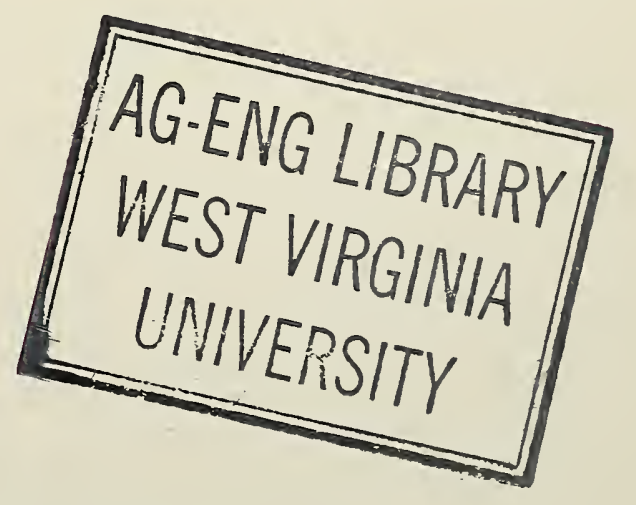

WEST VIRGINIA UNIVERSITY AGRICULTURAL EXPERIMENT STATION 


\section{THE AUTHOR}

Roger W. Pease, now retired, was Assistant Agricultural Economist in the West Virginia University Agricultural Experiment Station.

This bulletin is published as a contribution to the Northeast Regional Marketing Research Project in ornamentals (NEM-15). The West Virginia research basic to the data included was supported by both state and regional research funds.

West Virginia University Agricultural Experiment Station

College of Agriculture, Forestry, and Home Economics A. H. VanLandingham, Director MORGANTOWN 
Page

Summiary $\ldots \ldots \ldots \ldots \ldots \ldots \ldots \ldots \ldots . \ldots \ldots$

INFERENCES $\ldots \ldots \ldots \ldots \ldots \ldots \ldots \ldots \ldots$

INTRODUCTION $\ldots \ldots \ldots \ldots \ldots \ldots \ldots \ldots \ldots \ldots$

Procedure $\ldots \ldots \ldots \ldots \ldots \ldots \ldots \ldots \ldots \ldots \ldots$

Calls for Literature $\ldots \ldots \ldots \ldots \ldots \ldots \ldots . . \ldots$

Response to the Sketching Service ........ 10

Purchases by New Customers

from the Experimental Plots ........ 12

Consumier Attitudes and Responses . . . . . . . 13

UnCONTROLled Factors .............. 17 


\section{Summary}

URING the spring and early summer of 1961, the effects of a nursery-supplied information and landscape sketching service were measured. Two small and comparatively isolated cities were selected for the studies, one about 10 miles west and the other about 16 miles east of the cooperating nursery. No other full-time nursery was in the area. The economy of one city was dominated by two industrial concerns, one of which had ceased operations a few months before the trials started. The other city was the trading center for an agricultural area. Two private educational institutions were located in this city. In each city four plots of homes were selected, all characterized by comparatively recent building developments. One pair of plots was composed chiefly of "high-status" homes with an estimated average value of at least $\$ 20,000$; the estimated average value in the other pair of plots was between $\$ 15,000$ and $\$ 20,000$.

A series of informal, mimeographed pamphlets about ornamentals was prepared, and during February, the slack season for the nursery business, a brochure announcing the availability of the pamphlets was distributed to all owner-occupied homes in one plot (the trial) of each pair. When homeowners visited the nursery's garden center to obtain the pamphlets, they were notified that the free sketching service was available until March 15, or until ".... our book of appointments is filled." From the check plots, where the brochure had not been distributed, subsequent requests for the landscape sketching service were accepted but were not solicited. Until the second week of June, records were kept of: calls for the pamphlets, requests for the landscape sketches, landscape jobs resulting from the sketches, new-customer, gardencenter expenditures made by homeowners from the eight experimental plots. During July and August all of the homeowners in the experimental plots were interviewed by a worker not connected with the cooperating nursery. Information was obtained about the age, occupation, and income of homeowners; about the age and estimated value of homes; about homeowners' reactions to the pamphlets; and about attitudes toward the cooperating nursery in terms of intent to make further purchases.

The program's effect was negligible in the city where unemployment was common and a feeling of economic uncertainty was almost universal.

In the other city, about one-half of the homeowners within the higher status trial plot visited the garden center to procure at least one of the pamphlets. Only about one-fifteenth of the homeowners in the middle status trial plot called for pamphlets. About one-fifth of the 
owners in the higher status plot took advantage of the free sketching service, and the resultant income from landscape jobs, if distributed among all of the homeowners in the plot, would have amounted to about $\$ 38.00$ per home. No calls for sketches were made from the middle status plot.

In the same city, new customer garden-center purchases from the higher status trial plot would have amounted to about $\$ 6.00$ per home if the purchases were distributed among all of the plot's homeowners. In the higher status check plot, purchases distributed in a similar manner would have amounted to only $36 \dot{\phi}$ per person. The rate of purchase in the higher status trial plot (purchases per 100 homes) was about ten times as high as in any one of the other three plots. Among the other plots there were no significant differences in the rates of purchase.

Data obtained by the follow-up in this city showed that the offer of pamphlets was remembered by about three-fourths of the homeovvners in the higher status trial plots, but only about one-third in the middle status trial plot remembered the offer. New customer gardencenter expenditures, according to the plot-to-plot distribution, were negatively correlated with occurrence of family incomes of less than $\$ 10,000$, of home occupancy of more than 10 years and of house age of more than 5 years. No positive correlations were considered to be statistically significant. The analysis also indicated that some factor other than chance or the cumulative occurrence of these variables was associated with the distribution of new-customer garden-center expenditures. In the absence of evidence to the contrary, a logical inference is that the other factor was the impact of the experimental program.

\section{Inferences}

THE data obtained from the trials indicate that a free landscape sketching service exerts a considerable impact upon homeowners under certain conditions: The service should be limited to owner-occupants; homeowners in relatively high status areas are especially responsive; social status probably is more important than house valuation in determining response; costs are reduced if the service is limited to homeowners who, on their own initiative, make specific appointments. Probably the chief impact of the service is to change intent to action among homeowners who already plan to make landscape improvements "some time." The service also may influence homeowners to choose a professional landscape job instead attempting a "do-it-yourself" job.

The distribution of free literature about ornamentals, under certain circumstances, probably increases good will among old customers and 
entices some new customers to visit the nursery or garden center involved. The literature should be easily understood, highly informative, informal, and obviously a product of the nursery's own efforts, specific as to subject matter, and organized and written to suit local needs and desires. Such free literature apparently is appreciated by recipients in both high and middle status areas. By notifying homeowners that the literature is available, on call only, waste of the pamphlets and hence costs to the nursery may be reduced. Greater initial response to the notifications may be expected from high than from middle status areas.

In the area studied the stimulating effect on landscape expenditures which is exerted by relatively high incomes, new homes, and short occupancy periods does not fully compensate for the despressing effect of relatively low incomes, old homes, and long occupancy periods. 


\section{ORNAMENTALS-}

\section{Consumer Response to}

\section{Distribution of Literature \\ 2. A Free Landscape Sketching Service}

ROGER W. PEASE

\section{Introduction}

SURVEY of the northeast section of the United States showed that about one homeowner in three was unable to give the name of his favorite plant for foundation planting. About half expressed the need for more information about trees and shrubs, and the suggestion that nurserymen furnish more such information was made more often than any other. ${ }^{1}$ Homeowners who possessed drawn landscape plans for their property spent significantly more for ornamental plantings than owners who had no drawn plans. ${ }^{2}$ During 1961 the West Virginia University Agricultural Experiment Station conducted trials to test the applicability of these findings by measuring consumer responses to brochures offering free informative literature and free landscape sketching services. The trials also were designed to compare results from an industrial and a non-industrial city.

\section{Procedure}

A cooperating nursery was chosen which was the only full-time nursery within 50 miles of two relatively small cities where the test was conducted. Both of these cities were trading centers for sparsely populated areas. City A was 16 miles east from the cooperating nursery, across the Virginia state line, and on the other side of a mountain. However, a first-class road lead to City A, and local residents of West Virginia and Virginia frequently traveled back and forth for purposes

1The Technical Committee of the Northeast Regional Research Project, NEM15. Consumer Purchases and Preferences in Landscaping. Bul. 462, W. Va. Univ. Agr. Exp. Sta., June, 1961, p. 1.

Ibid. p. 22. 
of shopping and participation in sports. City A's economy was dependent upon two industrial plants whose expansion had caused the population to increase from about 6,000 persons to about 11,000 during a ten-year period. ${ }^{3}$ City $B$ had a population of about 2,000 persons, was 10 miles west from the cooperating nursery, and was the county seat of a relatively prosperous agricultural area. The economy of this city was partially dependent on a private boys' school and a girls' junior college.

A month before the tests were scheduled to start, the field worker's report on City A stated:

The general economic condition is not good. This ... is due to 700 men out of work (plant shut down). The sections we are using... are near the plant...they are afraid of what the future holds.

However, it was decided to start the trials as planned because results might indicate the effect of a local business recession on homeowners' expenditures for trees and shrubs. The chief purpose of the experiment would be to compare the trial and check plots in the high and middle status areas of City $B$.

Figure 1 shows the experimental design used in the two cities. Two pairs of modern, residential areas were chosen in each city. One pair in each city was estimated to contain high status homes with an average value of more than $\$ 20,000$; the other pair was estimated to contain middle status homes with an average value of $\$ 15,000$ to $\$ 20,000$. During February a brochure containing the following message was distributed to one plot of homes (the test plot) in each of the four pairs: ${ }^{4}$

We have prepared a series of pamphlets describing a few of the best landscape plants, how to plant them, how to care for them, how to prune them, and how to protect them from insects and disease. There will be no charge for the pamphlets. Pay us a visit; we value your good will.

\section{Very sincerely, SIGNED (manager)}

All homeowners within the four trial plots received the brochure. No brochures were distributed in the four check plots.

A short pamphlet was prepared on each of the topics listed. The pamphlets were multilithed on different-colored papers and were headed by the cooperating nursery's name and address. These pamphlets, stacked by color and topic, were placed in the nursery's garden center for distribution on request only.

${ }^{3}$ United States Census of Population, Number of Inhabitants, West Virginia, 1960 , Table 8.

"The brochure stipulated that the literature would be available until March. Heavy snow caused an extension of the deadline. Only owner-occupied homes were included in the experimental program. 
Figure 1. Experimental Design Used in Each of Two Cities

\begin{tabular}{|c|c|c|c|}
\hline & \multicolumn{2}{|c|}{ TEST CITY A (INDUSTRIAL) } & \\
\hline \multicolumn{4}{|c|}{ Estimated Average Value of Homes* } \\
\hline \multicolumn{2}{|c|}{ More Than $\$ 20,000$} & \multicolumn{2}{|c|}{$\$ 15,000$ to $\$ 20,000$} \\
\hline Trial & Check & Trial & Check \\
\hline Brochure & No Brochure & Brochure & No Brochure \\
\hline Plot No. 1 & Plot No. 2 & Plot No. 3 & Plot No. 4. \\
\hline
\end{tabular}

TEST CITY B (NON-INDUSTRIAL)

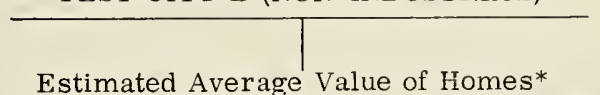

Estimated Average Value of Homes*

\begin{tabular}{|c|c|c|c|}
\hline \multicolumn{2}{|c|}{ More Than $\$ 20,000$} & \multicolumn{2}{|c|}{$\$ 15,000$ to $\$ 20,000$} \\
\hline Trial & Check & Trial & Check \\
\hline Brochure & No Brochure & Brochure & No Brochure \\
\hline Plot No. 5 & Plot No. 6 & Plot No. 7 & Plot No. 8 \\
\hline
\end{tabular}

${ }^{*}$ In this figure and all subsequent figures, the term homes is used to denote only owner-occupied homes.

A second brochure was given to consumers who called for the prepared literature. This brochure also bore the nursery's name and address and was worded as follows:

We are offering a landscape consultation service to home-owners who have visited us for these little pamphlets. If you need advice about landscaping your home, and if a sketch would help, telephone us at for an appointment. The service will be free until March $15^{5}$ or until our book of appointments is filled.

\section{SIGNED (manager)}

${ }^{5}$ Deadlines were set early in an effort to conduct the trials during the nursery's slack season. However, the landscape service was performed into April. 
The manager of the cooperating nursery was consulted on all phases of the study. He cooperated in preparing the brochures and pamphlets, and he performed the landscape sketching service himself. A former employee of the nursery was hired to spend full time in mapping all trial and all check plots, in supplying the pamphlets at the garden center, in obtaining the names and addresses of homeowners as they requested the landscape sketching service. ${ }^{6}$ New customers from both trial and check plots were noted, and the dollar value of their purchases was listed. ${ }^{\tau}$ These records were kept through the first week of June.

During the summer, in both City $A$ and City B, a follow-up survey was made of all homeowners in the experimental plots. Information was obtained about the income and occupation of the homeowners, about the age and value of homes, about visits to a nursery, and about reactions to the free services given during the experiment. Among the 302 owner-occupied homes in the experimental plots of cities $A$ and $B$, 259 questionnaires were completed.

\section{Calls for Literature}

Table 1 shows homeowner response to the brochure. It had been distributed only in the trial plots. In City B, requests for the pamphlets were made at the garden center by one-fifth of the homeowners who received the brochure. In City A the response was only about half as great. In both cities the response from owners in the higher status area was greater than from owners in the middle status area. In City B about one-half of the owners in the higher status plot requested literature while visiting the garden center. The unemployment and financial uncertainty in City A might explain the relatively poor response obtained there.

\section{Response to the Sketching Service}

Homeowner response to the free landscape sketching service is indicated in Table 2. In City $B$ the proportion of requests for the service was about three times as large as in City $A$, and the dollar value of resultant landscaping patronage was about eight times as large. Because fewer homeowners were tested in City B (135) than in City A

${ }^{6}$ Definite appointments for the sketching service were accepted if they were made at the garden center.

'During the rush season the manager's wife helped obtain data at the garden center. However, even with her help, the list of new customers probably was incomplete. 
(167), this difference in landscaping patronage was even more signifi. cant $^{\$}$ than the table indicates. Evidently the unemployment and finan. cial uncertainty in City $A$ had a greater effect upon responses to the landscape service than upon calls for literature.

About 85 per cent of the total income from the sketching service was derived from the two higher status plots in City B. Apparently homeowners within City B's two middle status plots had little interest in obtaining landscape plans for their property. The difference in responses between the higher status trial and check plots was inconclusive. The rate of patronage was about twice as great in the trial plot, but the per homeowner income derived was greater in the check plot because of one relatively large landscape job. Evidently, in City $B$ 's two higher status plots, there had been an extensive carry-over of information from the trial to the check even though the two plots were not adjoining. A substantial carry-over might be expected in so small a city.

\section{Purchases by New Customers from the Experimental Plots}

Table 3 compares garden center purchases by new customers from the experimental plots. Like patronage from the sketching service, new customer purchases indicated that the program exerted little influence in City A. The difference between City A's trial and check plots, in both rate and value of purchase, was insignificant. ${ }^{9}$ In City $B$, however, new-customer purchases from the trial plots were about four times as frequent and about three times as large as from the check plots. ${ }^{10}$

Table 4 lists further details about new-customer purchases from the experimental plots in City B. In the higher status trial plot, the rate of purchase and the average purchase value were about 20 times as high as in the parallel check plots. ${ }^{11}$ In the middle status plots, there was little difference between the rates of purchase, but the average value of purchase was much greater in the check than in the trial, because of one large purchase.

${ }^{8} \mathrm{~A}$ Chi Square value of 6.63 was needed to indicate significance at the 1 per cent level. A value of 745.34 was obtained.

${ }^{9}$ For the 5 per cent level, a Chi Square value of 3.84 was needed. Values of .158 and .653 were obtained.

${ }^{10}$ For the 1 per cent level, a Chi Square value of 6.63 was needed, and for the 5 per cent level, 3.84 was needed. Respective values of 4.91 and 18.00 were obtained.

${ }^{11}$ For the 1 per cent level, a Chi Square value of 6.63 was needed. Values of 9.60 and 79.48 were obtained. 
Table 3. Garden Center Purchases by New Customers in Cities A and $B$ (Data Obtained from Two Trial and Two Check Plots in Each of the Two Cities, 1961)

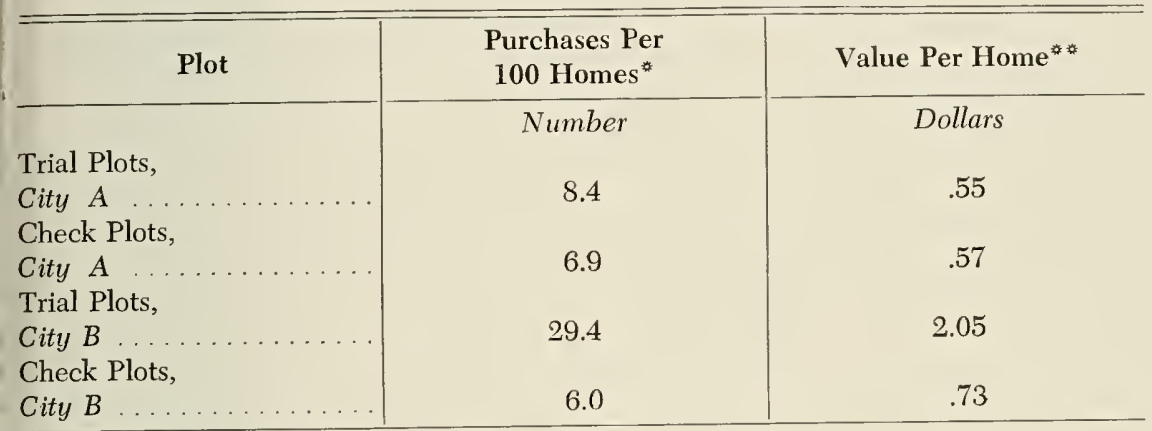

* Actually no plot contained 100 homes.

* In each group of plots, the total value of new-customer purchases divided by the total number of homes.

Table 4. Garden Center Purchases by New Customers in City $B$ (Data Obtained from Two Trial and Two Check Plots, 1961)

\begin{tabular}{|c|c|c|}
\hline Plot & $\begin{array}{c}\text { Purchases Per } \\
100 \text { Homes }\end{array}$ & Value Per Home \\
\hline & Per cent & Dollars \\
\hline Higher status & & \\
\hline Trial Plot ... & 80.8 & 6.43 \\
\hline Higher status & & \\
\hline Check Plot . & 4.5 & .36 \\
\hline Middle status & & \\
\hline Trial Plot ... & 6.8 & .12 \\
\hline Middle status & & \\
\hline Check Plot . & 7.1 & 1.03 \\
\hline
\end{tabular}

* Exclusive of plants sold as part of a landscape job.

* * See footnote, Table 3.

\section{Consumer Attitudes and Responses}

Table 5 shows the proportion of homeowners in the trial plots who, at the time of the survey, remembered the offer of free pamphlets about ornamentals. The proportions varied little between cities $A$ and $B .{ }^{12}$ However, the rate of recall in both cities was significantly greater ${ }^{13}$ in the higher than in the middle status brackets.

${ }^{12}$ Only the trial plots were included because the brochure about the pamphlets had been distributed only in the trial areas.

${ }^{13} \mathrm{~A}$ Chi Square value of 5.7 was obtained; 3.84 was needed for the 5 per cent level. 
Table 5. Homeowners' Recollection of the Offer of Free Landscape Pamphlets (Data Obtained from Two Trial and Two Check Plots in Each of Two Cities, 1961)

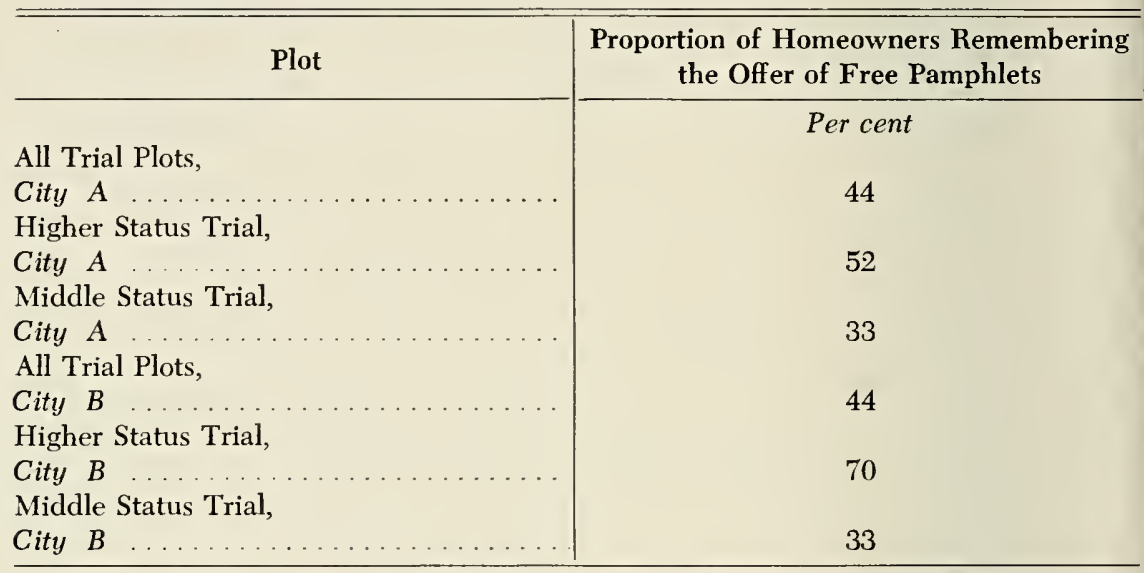

Table 6. The Proportion of Homeowners who Reported Various Sources of Information about Free Services or Materials (Data Obtained from Two Trial and Two Check Plots in Each of Two Cities, 1961)

\begin{tabular}{|c|c|c|c|c|}
\hline Plot & $\begin{array}{c}\text { Nursery } \\
\text { Repre- } \\
\text { sentative }\end{array}$ & Friend & $\begin{array}{l}\text { Visit to } \\
\text { Nursery }\end{array}$ & Other \\
\hline & $\begin{array}{l}\text { Per cent of } \\
\text { Homeowners }\end{array}$ & $\begin{array}{l}\text { Per cent of } \\
\text { Homeowners }\end{array}$ & $\begin{array}{l}\text { Per cent of } \\
\text { Homeowners }\end{array}$ & $\begin{array}{l}\text { Per cent of } \\
\text { Homeowners }\end{array}$ \\
\hline Upper Status & & & & \\
\hline Trial, City A & 50 & 0 & 4 & 2 \\
\hline Upper Status & & & & \\
\hline Check, City A & 23 & 3 & 6 & 14 \\
\hline Middle Status & & & & \\
\hline Trial, City A & 36 & 5 & 3 & 0 \\
\hline Middle Status & & & & \\
\hline Check, City A & 30 & 0 & 0 & 15 \\
\hline Upper Status & & & & \\
\hline Trial, City $B$ & 65 & 0 & 4 & 0 \\
\hline Upper Status & & & & \\
\hline Check, City B & 0 & 0 & 5 & 5 \\
\hline Middle Status & & & & \\
\hline Trial, City B & 33 & 0 & 2 & 0 \\
\hline Middle Status & & & & \\
\hline Check, City B & 5 & 0 & 0 & 0 \\
\hline
\end{tabular}

" Percentages are not additive. Not included in the table are the homeowners who did not remember about the service or about the source of information. 
No representative from the cooperating nursery had called on homeowners in the checks plots of either City A or City B. However, in City A's check plots about one-quarter of the homeowners reported that some nursery representative had told them about available free services or materials (Table 6). In City B's check plots only one homeowner ( 5 per cent of the middle home-valuation bracket) so reported. This difference between City $A$ and City $B$ would have happened by chance less often than once in one hundred times. ${ }^{1+}$ The data suggest that in City A some other nursery had competed with the cooperating concern in obtaining patronage by the performance of free services, and that City A's homeowner responses might give an erroneous impression of the impact of the experimental trials. For this reason no further analysis was made of the data from City A. However, the data obtained about calls for literature, response to the sketching service, and new-customer purchases, indicate that the business depression in City $A$ had made the experimental program ineffective in that city.

Table 7 shows the proportions of pamphlet recipients in City B who identified each of the five pamphlets by subject matter. The pamphlet on sprays and dusts was remembered most often, but by a nonsignificant margin. ${ }^{15}$ The recall of subject matter was not significantly ${ }^{16}$ greater in the higher than in the middle status bracket. Therefore, valid comparisons cannot be made about the impact of the various pamphlets. However, the data indicate that at least one-quarter of the material was read carefully enough to fix the subject matter in the readers' minds. In both the higher and middle status brackets, about three-quarters of the recipients reported that the pamphlets were especially useful (Table 8).

In terms of sources where homeowners preferred to make future landscape purchases,${ }^{17}$ the impact of the experimental trials apparently was negligible. In the higher status trial and check plots the same proportions expressed preference for the cooperating nursery (Table 9 ); and the difference between the rates of preference among owners in the middle status plots was not significant. ${ }^{18}$ Although relatively

${ }^{14} \mathrm{~A}$ Chi Square value of 6.63 was needed for significance at the 1 per cent level; 8.20 was obtained.

${ }_{15} \mathrm{~A}$ Chi Square value of 9.49 was needed for the 5 per cent level; 1.90 was obtained.

${ }^{15} \mathrm{~A}$ Chi Square value of 3.84 was needed for the 5 per cent level; a value of 1.33 was obtained.

1'This information was obtained by asking respondents to check one of the following as their preference for future patronage; Mail Order, Agent, Trucker, Nursery within 5 miles, Store, Nursery more than 5 but less than 25 miles away, Nursery 25 miles or more away, Other.

${ }_{18} \mathrm{~A}$ Chi Square value of 3.84 was needed for the 5 per cent level; a value of 1.03 was obtained. 
Table 7. Identification of Pamphlets by Subject Matter (Data Obtained from a Follow-up Survey of Homeowners in Two Trial Plots in City B, 1961)

\begin{tabular}{l|c|c|c|c|c}
\hline \hline \multicolumn{1}{c}{ SUBJECT MATTER * } \\
\hline \\
\hline
\end{tabular}

${ }^{*}$ Per cents are not additives. Some homeowners had received all five pamphlets. Some could identify several pamphlets by subject matter.

* The recipients in the higher and middle status numbered only 13 and 4 , respectively.

Table 8. Pamphlet Recipients who Found Pamphlets Especially Useful (Data Obtained from Two Trial Plots in City B, 1961)

\begin{tabular}{|c|c|c|}
\hline Plot & Recipients & $\begin{array}{c}\text { Proportion of Recipients } \\
\text { Who Found the Pamphlets } \\
\text { Especially Useful }\end{array}$ \\
\hline $\begin{array}{l}\text { Both Trial Plots, City B } \\
\text { Higher Status Trial, City } B \\
\text { Middle Status Trial, City } B\end{array}$ & $\begin{array}{l}\text { Number } \\
17 \\
13 \\
4\end{array}$ & $\begin{array}{c}\text { Per cent } \\
71 \\
70 \\
75\end{array}$ \\
\hline
\end{tabular}

Table 9. Preferred Sources for Future Purchases (Data Obtained from Two Trial and Two Check Plots in City B, 1961)

\begin{tabular}{l|c|c}
\hline \multirow{2}{*}{ Plot } & \multicolumn{2}{|c}{ RESPONDENTS WHO PREFERRED: } \\
\cline { 2 - 3 } & & Other Source \\
\hline & Cooperating Nursery & Per cent \\
All Plots, City B . . . . . . . & 52 & 48 \\
Higher Status Trial, City B . . & 67 & 33 \\
Higher Status Check, City B ... & 67 & 33 \\
Middle Status Trial, City B . . & 42 & 58 \\
Middle Status Check, City B ... & 48 & 52 \\
\hline
\end{tabular}

*The cooperating nursery was identified indirectly by distance from respondents' homes. No preference was stated by 7 among 259 respondents. 
more owners in the higher than in the middle status brackets preferred to buy from the cooperating nursery, this difference, also, was not significant. ${ }^{19}$

\section{Uncontrolled Factors}

Various uncontrolled variables instead of the experimental program might have caused the differences in new-customer, garden-center expenditures among City B's four experimental plots. The fact that the garden center was only two years old would have influenced patronage equally in all trial and check plots. Therefore, the age of the garden center may be discounted as an explanatory factor. However, the following seven uncontrolled variables were selected as the most probable causes for the differences involved: homeowner age, homeowner occupation, more than one family member gainfully employed, value of home, family income, period of home occupancy, and house age. The homeowner survey had obtained pertinent data from all four plots in City B. These data showed the frequency of occurrence for various categories of the seven variables (Table 10).

To ascertain the relationship between new-customer, garden-center expenditures and the listed variables, three tests were made. First, a test for simple correlation ${ }^{20}$ showed whether the number of homes characterized by each category of the variables tended to increase or decrease from plot to plot in unison with expenditures. Similarity of direction rather than amount of change was indicated by this test. Second, those categories were selected which showed a decided tendency to change in unison with expenditures, and a test was made ${ }^{21}$ to indicate if some factor other than these selected categories was associated with expenditure changes. Measurement of degree rather than of direction of change was made by this test. Third, within each plot, the numbers of homes characterized by the selected categories were added. A test then was made to indicate if an association existed between expenditures and some factor other than the cumulative occurrence of the selected categories. ${ }^{22}$

Table 11 lists the results of the first test. Because the number of cases involved was small, only coefficients of .8333 or more were in-

${ }^{19} \mathrm{~A}$ Chi Square value of 3.84 was needed for the 5 per cent level; a value of 3.64 was obtained.

${ }^{20}$ Rank Correlation Methods, M. G. Kendall.

${ }^{21}$ Goodness of fit. Chi Square. New-customer, garden-center expenditures were re-distributed according to each of the selected categories, and the relationship between the observed and each of these theoretical distributions was tested.

${ }^{22}$ Same as footnote 21 , above, except that the cumulative occurrences of the categories were used. 
Table 10. Categories of Uncontrolled Variables Used FOR ANALysis, 1961

\begin{tabular}{l|l}
\hline \hline Uncontrolled Variables & \multicolumn{1}{|c}{ Categories } \\
\hline Homeowner & Less than $30 \mathrm{yrs.}$ \\
Age & $30-59$ yrs. \\
& 60 yrs. or more \\
\hline Two Or More Family & \\
Members Employed & \\
\hline House & Less than $\$ 10,000^{*}$ \\
Value & $\$ 10,000-\$ 19,000$ \\
& $\$ 20,000$ or more \\
\hline Family & Less than $\$ 10,000$ \\
Income & $\$ 10,000$ or more \\
\hline Homeowner's & Non-professional \\
Occupation & Professional ${ }^{*}$ \\
\hline & Less than 5 yrs. \\
Period of & $5-9$ yrs. \\
Occupancy & $10-19$ yrs. \\
& 20 yrs. or more \\
\hline & Less than 5 yrs. \\
House Age & $5-9$ yrs. \\
& $10-19$ yrs. \\
& 20 yrs. or more \\
\hline
\end{tabular}

"Homeowners' estimates varied from the original estimates by the field worker. * Only clergymen, doctors, lawyers, and educators were included.

terpreted to indicate significant correlations. Family incomes of less than $\$ 10,000$; home occupancy of $10-19$ years and 20 years or more; and house ages of $5-9,10-19$, and 20 years or more showed distinct negative correlations. That is, the occurrence of each of these categories tended to increase from plot to plot when expenditures decreased, and to decrease when expenditures increased.

House age and period of occupancy are redundant in that occupancy cannot exceed the age of the house occupied. However, short periods of occupancy occur when old houses are occupied by recent purchasers. Many old homes are extensively landscaped. Therefore, house age might be expected to show greater correlation with expenditures than period of occupancy-especially in the less-than-five-year category. Table 11 supports this hypothesis. In the less-than-five-year category, period of occupancy showed no correlation (.0) with expenditures, but house age showed a positive but non-significant correlation (.6667). Since all other categories of house age showed distinct negative correlations with expenditures, a positive correlation greater 
Table 11. Coefficients of Correlation * Between New-Customer Garden-Center Expenditures and Various Categories of Uncontrolled Variables, 1961

\begin{tabular}{|c|c|c|}
\hline \multicolumn{2}{|c|}{ Categories } & \multirow{2}{*}{$\begin{array}{c}\begin{array}{c}\text { Coefficients of Correla- } \\
\text { tion with Expenditures }\end{array} \\
-.3333 \\
.0 \\
-.3333\end{array}$} \\
\hline Owner Age & $\begin{array}{l}\text { Less than } 30 \text { years } \\
30-59 \text { years } \\
60 \text { years or more }\end{array}$ & \\
\hline $\begin{array}{l}\text { Two or More } \\
\text { Family Mem- } \\
\text { bers Employed }\end{array}$ & & .0 \\
\hline House Value & $\begin{array}{l}\text { Less than } \$ 10,000 \\
\$ 10,000-\$ 19,999 \\
\$ 20,000 \text { or more }\end{array}$ & $\begin{array}{l}-.6667 \\
-.3333 \\
.0\end{array}$ \\
\hline $\begin{array}{l}\text { Family } \\
\text { Income }\end{array}$ & $\begin{array}{l}\text { Less than } \$ 10,000 \\
\$ 10,000 \text { or more }\end{array}$ & $\begin{array}{r}-.8333 \\
.3333\end{array}$ \\
\hline $\begin{array}{l}\text { Homeowner } \\
\text { Occupation }\end{array}$ & $\begin{array}{l}\text { Non-professional } \\
\text { Professional }{ }^{* *}\end{array}$ & $\begin{array}{l}.0 \\
-.3333\end{array}$ \\
\hline $\begin{array}{l}\text { Period of } \\
\text { Home } \\
\text { Occupancy }\end{array}$ & $\begin{array}{l}\text { Less than } 5 \text { years } \\
5-9 \text { years } \\
10-19 \text { years } \\
20 \text { years or more }\end{array}$ & $\begin{array}{r}.0 \\
.0 \\
-1.0 \\
-1.0\end{array}$ \\
\hline $\begin{array}{l}\text { House } \\
\text { Age }\end{array}$ & $\begin{array}{l}\text { Less than } 5 \text { years } \\
5-9 \text { years } \\
10-19 \text { years } \\
20 \text { years or more }\end{array}$ & $\begin{array}{r}.6667 \\
-.6667 \\
-.8333 \\
-1.0\end{array}$ \\
\hline
\end{tabular}

${ }^{*}$ Rank Correlation Methods, M. G. Kendall. A coefficient of 1.0 shows that the variables measured increased or decreased in unison. In this study, only coefficients of .8333 or greater were interpreted to indicate a significant degree of correlation.

* See footnote, Table 10 .

than this .6667 might be expected for the less-than-five-year category. A similar contradiction also existed in the family-income categories. Since the less than $\$ 10,000$ category showed a distinct negative correlation with expenditures, a positive correlation of more than the actual .3333 might be expected for incomes of $\$ 10,000$ or more. This apparent enigma indicates that owner-occupants of relatively old homes and relatively low income owner-occupants of all homes spent so little for ornamentals that their presence more than offset the stimulating effect of homes less than five years old and of relatively high income families. Therefore, the presence of old houses and relatively low income families in a neighborhood may be more important than the presence of newly built residences and high incomes in determining the impact of a program to increase nursery sales. 
Test 1 measured correlation in direction but not in degree of change. The six categories which, in Test 1 , had shown coefficients of at least .8333 were subjected to Test 2 . The results of this test ${ }^{23}$ indicated that some factor other than chance or any one of the six selected categories was associated with the degree of plot-to-plot changes in expenditures. Either the impact of the experimental program or the cumulative effect of the six selected categories (possibly both) may have been this other factor. However, results of Test 3 showed a significant association between expenditures and some factor other than chance or the cumulative impact of the selected categories. ${ }^{24}$ In the absence of evidence to the contrary, it is logical to assume that the impact of the experimental program was this other factor, and that the association was casual in nature.

${ }^{23} \mathrm{~A}$ Chi Square value of 7.81 was needed to show significance at the 1 per cent level; the obtained values were $6777.82,4453.28,1997.20,1839.95,624.40$, and 472.03 .

${ }^{24} \mathrm{~A}$ Chi Square value of 7.81 was needed to show significance at the 1 per cent level; a value of 950.34 was obtained. 

